\title{
Multiple Avalons: Place naming practices and a mythical Arthurian island
}

\author{
Philip Hayward \\ University of Technology Sydney, Australia \\ LabX, Southern Cross University, Lismore, Australia \\ prhshima@gmail.com
}

\begin{abstract}
The island of Avalon features in British Arthurian legendry. While its very existence - let alone any actual location it may have had — is contentious, it is now commonly associated with Glastonbury, in the English county of Somerset. Illustrating its enduring appeal, Avalon's name has also been affixed to a number of international locations over the last 500 years. There have been various motivations for such place naming, including religious beliefs, personal associations, and various types of boosterism, all attempting to imbue New World locales with Old World mystique through nomenclative association. This article surveys the deployment of the concept of Avalon through anglophonic colonial and postcolonial place naming and examines the varying ways in which the name has been applied in different national and local contexts. Its survey reveals direct references to the legendary isle in place naming between the $17^{\text {th }}$ and early $20^{\text {th }}$ centuries and, generally, more weakly associative and/or arbitrary connections over the last century. The study contributes to the expansion of island studies by analysing how a mythical island has been projected onto various non-island locations, and contributes to the development of toponymic studies by examining multiple uses of a single place name.
\end{abstract}

Keywords: Avalon, Arthurian legend, colonial place naming, destination branding

https://doi.org/10.24043/isj.174 • Received April 2021, Early access August 2021

(C) Island Studies Journal, 2022

\section{Introduction}

This article begins with discussion of the mythical island of Avalon, and then addresses the nature of a range of international locales named after it. It is thereby lodged at the intersection of toponymy and the interdisciplinary field of island studies. Toponymy has gained tentative traction in island studies in recent years, chiefly through a themed section on the topic edited by Joshua Nash in Island Studies Journal (ISJ) in 2016 and by Nash's broader contributions to the field (e.g., Nash, 2009, 2013). In his introduction to the 2016 ISJ thematic section, Nash (2016, p. 342) proffered its contents "to islanders, island studies scholars, islophiles, toponymists and linguists, as well as anthropologists, geographers and historians," noting that it is "by encouraging and participating in more innovative intellectual research based on island toponymies, languages and histories, and their interaction with islandness and insularity, that a more synthesized and personalized academic product might emerge." Despite Nash's 
ambition, and the breadth and accomplishment of material included in the ISJ thematic section, there have been few "synthesized" or "personalized" toponymic articles published in island studies journals in the last five years. In the discussions that follow, I am less interested to follow Nash's (2016, p. 339, emphasis added) challenge to establish "island toponymy as a subfield of research in its own right both within island studies and toponymy more generally" than I am to pursue an expanded concept of island studies that includes the study of island terms and concepts that have been diffused into broader contexts. I commence my analysis by discussing the origins of Avalon as a mythic island that has come to be strongly associated with Glastonbury, in the English county of Somerset, and then map the dispersal of the Avalon name and its associations to Australia, Canada, New Zealand, and the United States: those countries whose place name registers show inhabited areas (ranging from hamlets to cities) and/or geo- or hydro-graphical features named Avalon.

In several previous analyses of place names, researchers have placed considerable emphasis on "pristine" examples, where the researcher has information concerning "the actual act of its creation" (Ross, 1958, p. 333). Throughout my account of the international distribution of the place name 'Avalon', I have included as much data as I have been able to obtain concerning motivations for place naming in order to contribute to an overall picture of international uses of the term. In this manner, my study is located between the key toponymy research paradigms identified by Tent (2015): an intensive or "semasiological" (Coates, 2013) approach that looks at the origins and motivations for the choice of individual place names; and an extensive one that is premised on understanding systematic patterns of place naming in broader contexts. I have tried to contribute to the reconciliation of the two approaches suggested by Nash $(2015$, p. 235) by evaluating the "constitution and operation" of toponyms and considering the extent to which they represent "non-arbitrary elements" of a "lexicon" used by people to delineate features in a landscape and to imbue these with meanings. More specifically, the article documents and analyses a particular example of anglophone colonial - and subsequently postcolonial — place naming. Colonial place names (CPNs) have been defined as:

a specific category of toponyms, namely the class of place names which are attested in documents of the era of colonialism (c. 1415-c. 1999) as labels employed (a) by (mostly European) colonizers for reference to geo-objects in the territory of the (mostly extra-European) colonized or (b), most frequently in the shape of streetnames commemorating events, person, or places related to the colonialist enterprise, as expression of colonial ambitions of (mostly European) colonizers in their homecountries. (Stoltz et al., 2020)

In this article I concentrate on the former category, referring to "geo-objects" of various types (primarily landscape features and settlements of various sizes) and the extent to which they commemorate aspects of a referent locale (Avalon, in Somerset) and associations accruing to it. With particular regard to the allocation of Avalon place names in the US in the $20^{\text {th }}$ century, referred to in Section III, I draw on Alderman (2008, pp. 196-197) to examine the manner in which naming has been "used by developers to create place identities that promote idyllic yet often socially exclusive historical representations" that provide "comfort and prestige," catering for and nurturing a nostalgia for an imagined ancestral homeland. With regard to 
island studies' perspectives, research for this article has — somewhat surprisingly — identified very few islands named Avalon. The majority of the article consequently explores how a particular concept of romantic islandness has been applied to a variety of non-island locations. The Avalons dispersed across the planet by British colonialism were initially located on coasts but increasingly have been established in inland locations with no direct connection to aquatic spaces. The original concept and referent of Avalon has thereby been diffused and rendered via more general — rather than specifically islandish — associations.

Table 1: Geographical coordinates of Avalon places identified in article.

\begin{tabular}{|l|l|}
\hline Avalon (Catalina Island, USA) & $33^{\circ} 20^{\prime} 27^{\prime \prime} \mathrm{N}, 118^{\circ} 19^{\prime} 40^{\prime \prime} \mathrm{W}$ \\
\hline Avalon (Georgia, USA) & $34^{\circ} 30^{\prime} 55^{\prime \prime} \mathrm{N}, 83^{\circ} 12^{\prime} 28^{\prime \prime} \mathrm{W}$ \\
\hline Avalon (Maryland, USA) & $38^{\circ} 42^{\prime} 28^{\prime \prime} \mathrm{N}, 76^{\circ} 20^{\prime} 03^{\prime \prime} \mathrm{W}$ \\
\hline Avalon (Mississippi, USA) & $33^{\circ} 39^{\prime} 23^{\prime \prime} \mathrm{N}, 9^{\circ} 04^{\prime} 52^{\prime \prime} \mathrm{W}$ \\
\hline Avalon (New Jersey, USA) & $39^{\circ} 05^{\prime} 28^{\prime \prime} \mathrm{N}, 74^{\circ} 43^{\prime} 32^{\prime \prime} \mathrm{W}$ \\
\hline Avalon (New South Wales, Australia) & $33^{\circ} 37^{\prime} 50^{\prime \prime} \mathrm{S}, 151^{\circ} 19^{\prime} 02^{\prime \prime} \mathrm{E}$ \\
\hline Avalon (Newfoundland, Canada) & $47^{\circ} 01^{\prime} 46^{\prime \prime} \mathrm{N}, 52^{\circ} 53^{\prime} 04^{\prime \prime} \mathrm{W}$ \\
\hline Avalon (North Carolina, USA) & $36^{\circ} 25^{\prime} 41^{\prime \prime} \mathrm{N}, 79^{\circ} 56^{\prime} 51^{\prime \prime} \mathrm{W}$ \\
\hline Avalon (Ontario, Canada) & $45^{\circ} 16^{\prime} 02^{\prime \prime} \mathrm{N}, 76^{\circ} 32^{\prime} 42^{\prime \prime} \mathrm{W}$ \\
\hline Avalon (Victoria, Australia) & $38^{\circ} 03^{\prime} 13^{\prime \prime} \mathrm{S}, 144^{\circ} 25^{\prime} 46^{\prime \prime} \mathrm{E}$ \\
\hline Avalon/Glastonbury (Somerset, UK) & $51^{\circ} 08^{\prime} 42^{\prime \prime} \mathrm{N}, 2^{\circ} 42^{\prime} 46^{\prime \prime} \mathrm{W}$ \\
\hline Avalon Dairy (British Columbia, Canada) & $49^{\circ} 11^{\prime} 19^{\prime \prime} \mathrm{N}, 122^{\circ} 59^{\prime} 03^{\prime \prime} \mathrm{W}$ \\
\hline Avalon Gardens (California, USA) & $33^{\circ} 57^{\prime} 30^{\prime \prime} \mathrm{N}, 118^{\circ} 15^{\prime} 42^{\prime \prime} \mathrm{W}$ \\
\hline Avalon Marshes (Somerset, UK) & $51^{\circ} 10^{\prime} 11^{\prime \prime} \mathrm{N}, 2^{\circ} 49^{\prime} 24^{\prime \prime} \mathrm{W}$ \\
\hline Avalon Organic Gardens/EcoVillage (Arizona, USA) & $31^{\circ} 34^{\prime} 39^{\prime \prime} \mathrm{N}, 111^{\circ} 02^{\prime} 29^{\prime \prime} \mathrm{W}$ \\
\hline Avalon Park (British Columbia, Canada) & $49^{\circ} 12^{\prime} 19^{\prime \prime} \mathrm{N}, 123^{\circ} 01^{\prime} 48^{\prime \prime} \mathrm{W}$ \\
\hline Avalon Park (Florida, USA) & $28^{\circ} 30^{\prime} 42^{\prime \prime} \mathrm{N}, 81^{\circ} 09^{\prime} 16^{\prime \prime} \mathrm{W}$ \\
\hline Avalon Plantation (Louisiana, USA) & $29^{\circ} 38^{\prime} 02^{\prime \prime} \mathrm{N}, 91^{\circ} 23^{\prime} 53^{\prime \prime} \mathrm{W}$ \\
\hline Avalon Pond (British Columbia, Canada) & $49^{\circ} 12^{\prime} 05^{\prime \prime} \mathrm{N}, 123^{\circ} 01^{\prime} 58^{\prime \prime} \mathrm{W}$ \\
\hline
\end{tabular}

In the early years of European colonial expansion, place naming was an ad hoc practice with many initial names falling into obscurity and/or disuse. Given the diffusion of the place name 'Avalon' beyond Britain from the Elizabethan period on, there may well have been other places named Avalon that have been lost to the historical record (and are, therefore, not included in this analysis). The place names considered in this article are all ones that have persisted to the present and derive from a separately published data set (Hayward, 2021). The data set was developed from entries in the United States Geological Survey (USGS; US Board on Geographic Names, n.d.), the Australian ICSM (Intergovernmental Committee on Surveying and Mapping, n.d.), the Canadian Geographical Names Database (Government of Canada, n.d.), and the New Zealand Gazetteer (Toitū Te Whenua: Land Information New Zealand, 2018), cross referenced against Google Maps search data. The place names data obtained from these sources was filtered to exclude buildings, businesses, municipal offices, et cetera, and isolated the inhabited places and geographical/hydrological features that include the term 'Avalon' in their name. The 2021 dataset lists 84 principal locations and a further 20 
that derive from a primary one (e.g., Avalon Wilderness Reserve, which derives its name from its location on the broader Avalon Peninsula). 78\% of Avalon principal place names are located in the US, $13 \%$ in Canada, and $4.5 \%$ each in Australia and New Zealand. This article also draws on material obtained from internet searches and correspondence with local history societies and historians on the origins of particular Avalon place names.

The article is divided into three sections. The first addresses the establishment of the Avalon myth and its application to an area of Newfoundland in the $17^{\text {th }}$ century. The second examines the popularity of Tennyson's Arthurian verse in $18^{\text {th }}$ century North America and Australia and related place naming, and the third discusses trends in $20^{\text {th }}$ and $21^{\text {st }}$ century distribution of the term. The geographical co-ordinates of each Avalon identified in the article are detailed above in Table 1.

\section{Myths of Avalon and the establishment of the Newfoundland colony}

The legendary island of Avalon is directly derived from the Spanish scholar Isidore of Seville's Etymologiae (published in the $7^{\text {th }}$ century and reprinted in various version across Europe during the Renaissance). In a section on islands, he refers to the Fortunatarum insulae ('fortunate islands") as "happy and blessed with an abundance of fruit" resulting in "the mistake of pagans and the poems by worldly poets, who believed that these isles were Paradise because of the fertility of their soil" (Barney et al., 2006, p. 294). Whether these islands were purely mythical or else represented fanciful interpretations of actual locations, Isidore's description inspired the $12^{\text {th }}$ century English historian Geoffrey of Monmouth to condense the Fortunatarum insulae into a single island in his account of the life of the seer Merlin, Vita Merlini (ca. 1150). Geoffrey introduces the "island of apples" as a place called "the Fortunate island [...] because it produces all things for itself." As he elaborates:

There is no work for the farmers in plowing the fields, all cultivation is absent except for what nature manages by herself. On its own the island produces fertile crops and grapes and native apples by means of its own trees in the cropped pastures. On its own the overflowing soil puts forth all things in addition to the grass, and in that place one lives for one hundred years or more [...] To that place after the battle of Camblan we brought Arthur, hurt by wounds, with Barinthus leading us, to whom the waters and the stars of the sky were known. (Geoffrey of Monmouth, ca. 1150/1995)

While early accounts of the island do not suggest actual locations for it, the $12^{\text {th }}$ century cleric Gerald of Wales (1193/2001, para. 12) provided the following specification (and etymological explanation) of what he characterises as Arthur's last resting place:

It is called Avalon, either from the British word aval, which means pomum, because apples and apple trees abound in that place; or, from the name Vallo, once the ruler of that territory. Likewise, long ago the place was usually called in British Inis Gutrin, that is, insula vitrea, evidently on account of the river, most like glass in colour, that flows around the marshes. Because of this, it was later called Glastonia in the language of the Saxons who seized this land, since glas in English or in Saxon means vitrum. It 
is clear from this, therefore, why it was called an island, why it was called Avalon, and why it was called Glastonia.

Gerald's characterisation that the low-lying lands around Glastonbury in the pre-Medieval period were marshy and were fragmented by rivers is accurate (Rippon, 2008; see Figure 1) and supports Glastonbury being considered as a presqu'île (a peninsula with islandish aspects) at this time. The juxtaposition of this accurate characterisation, some speculative place name etymology and a projection of Isidore's and Geoffrey's mythic locale on to Glastonbury established a tradition of Avalon as located in the West of England that has persisted to the present and was promoted strongly by influential British author Geoffrey Ashe in his 1957 volume King Arthur's Avalon: The Story of Glastonbury.

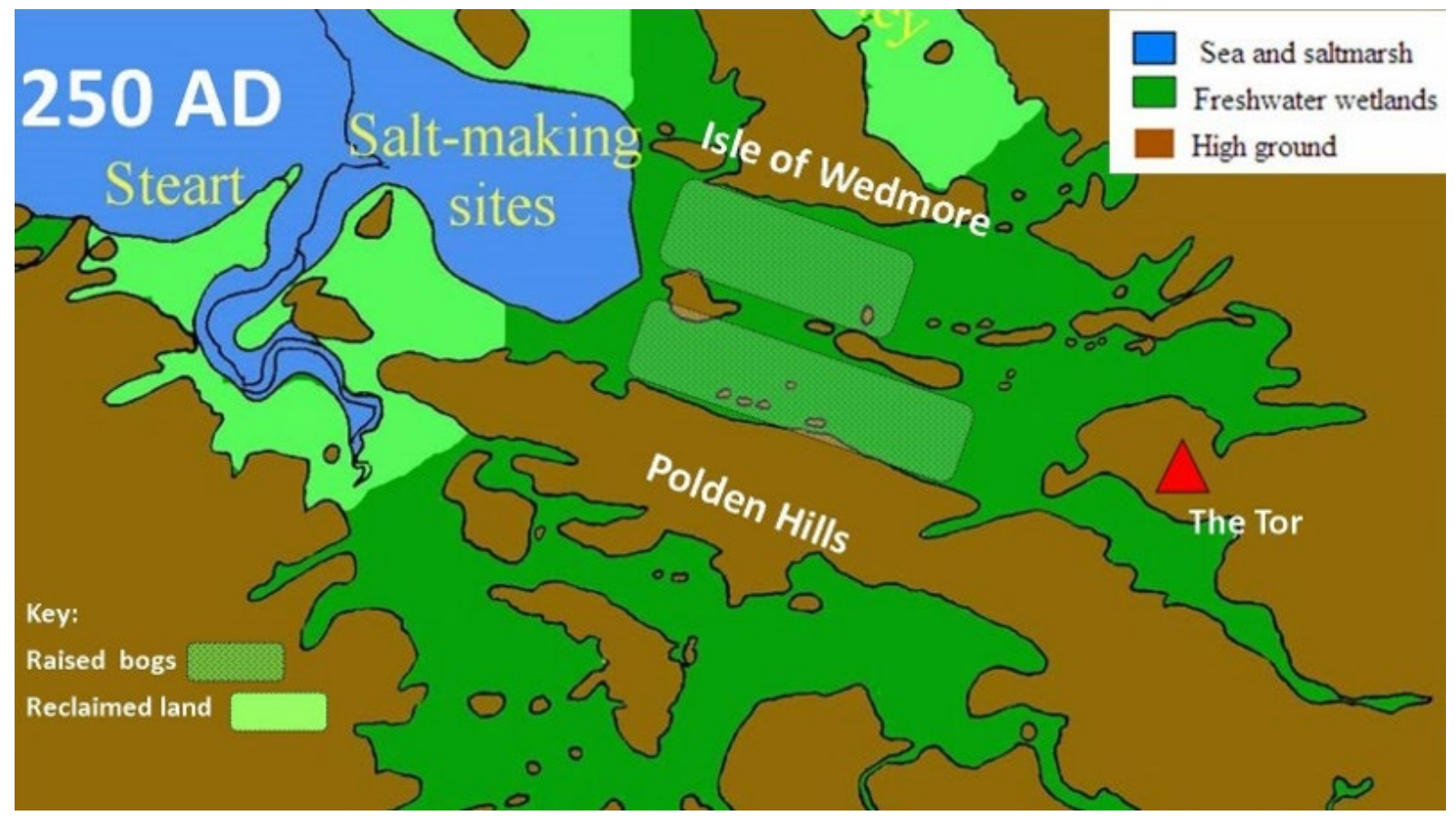

Figure 1: Landscape around Glastonbury Tor (250 AD), showing the Tor (indicated by red triangle) surrounded on three sides by freshwater wetlands. Source: South West Heritage Trust.

Gerald of Wales' account was also significant for identifying that Arthur's grave was located in Glastonbury and that it was marked by a cross, an element that wove Christianity into the mytho-historic narrative. As Cusack (2018) has detailed, Gerald's theme was influential in the promotion of Glastonbury as a holy place between the $12^{\text {th }}$ and $14^{\text {th }}$ centuries with regard to myths that included supposed visits by Jesus and Joseph of Arimathea (during which they established a chapel), the sprouting of a stick into a sacred hawthorn tree, and the presence of the Holy Grail (the cup which Jesus used at the Biblical Last Supper and/or in which Joseph gathered drops of Jesus's blood during his crucifixion) in the area. In 1191, further cachet was attached to Glastonbury Abbey (founded in the $7^{\text {th }}$ century) when its monks claimed to have uncovered Arthur's grave and the cross referred to by Gerald. Their claim appears to have been accepted at face value, spurring a lucrative pilgrimage trade and prompting the English monarchy to embrace the Arthurian connection through their patronage of the Abbey. As Cusack (2018, p. 313) has identified: 
The core elements of the 'Somerset tradition' are diverse but coalesce to form a consistent whole. The Thorn, the Grail, and the church erected by Joseph and Jesus, all function to sanctify Avalon as the Holy Land and to shift England from the periphery to the centre of the Christian world.

The enduring appeal of Arthurian legendry was further enhanced by the publication of Thomas Malory's epic prose work Le Morte d'Arthur (1485), which drew on early English literature and anglicised various related themes from French literature and legendry. Malory's text proved highly popular and was republished multiple times in the $16^{\text {th }}$ and $17^{\text {th }}$ centuries, maintaining a high-profile for the Arthurian tradition in the Tudor period (inaugurated in the year of the book's publication when Henry VII gained the crown). But, while the historical romance of Arthur may have enjoyed prominence at this time, its association with English Christianity came under attack during the reign of King Henry VIII (1491-1547). His rejection of the Roman Catholic Church, adoption of Protestantism as a state religion, and the passing of The Suppression of Religious Houses Act in 1536 interrupted the aforementioned 'Somerset tradition', casting it as religious superstition. Reflecting this, the Abbot of Glastonbury was seized and executed in 1539, the Abbey dissolved, and its buildings vandalised. Despite the sweeping changes to many aspects of the Church during the Reformation, English Catholics continued to cherish a variety of beliefs concerning Glastonbury and the early Golden Age of English Christianity it was perceived to represent. Indeed, one such belief, in the holiness of Glastonbury's hawthorn tree, returned to prominence during the rule of King James I (1603-1625), when the tree was held as symbol of religious tolerance and of rapprochement between Protestants and Catholics (Cusack, 2018, p. 314). This Tudor context is directly relevant to the first international location to be named after Avalon: a large peninsula on the south-east corner of the island of Newfoundland. This area was the site of England's first colony and, indeed, of one of the first continuing European settlements in North America.

The name 'Avalon' first became associated with the eastern coast of the Avalon Peninsula around the port of Ferryland when Sir George Calvert was awarded the area by the British Crown in 1623, with the name (and his domain) subsequently being extended to the whole peninsula (Colony of Avalon Foundation, n.d.; Wood, 2000). At the time of English settlement, the Indigenous Beothuk inhabitants of the peninsula appear to have substantially withdrawn from the region and little is known about their inhabitation of the peninsula or their names for particular places within it (Colony of Avalon Foundation, 2016). In a volume published in 1662, the English historian and clergyman Thomas Fuller (1881, p. 508) asserted that the area formerly known as Ferryland had been named by Calvert "in imitation of old Avalon in Somerset-shire wherein Glassenbury stands, the first-fruits of Christianity in Britain." This characterisation has subsequently been reproduced in a range of media and appears to be commonly accepted despite the lack of an attributed primary source for Calvert's intentions. One reason for its acceptance is that it is eminently plausible. Calvert was a highly religious man. He was born into a Catholic family and while required to adopt the Protestant faith as the result of religious repression under Queen Elizabeth I, he retained an interest in Catholicism during the subsequent rule of King James I that was affirmed by his official conversion to Catholicism in 1625. Following this, he crossed the North Atlantic to reside on the Avalon Peninsula in 1627-1629, promoting the area as a refuge for Catholics through 
a policy of free worship. But, despite this orientation, he was also an opportunist and his initial interest in Avalon was, in all likelihood, commercial as well as spiritual. Whatever the case, the name became established, and Newfoundland's Avalon Peninsula became the first overseas place named after the legendary English isle. In an associated process, the narrow neck of land connecting the peninsula to the Newfoundland mainland also became known as the Avalon Isthmus and, many years later, the Avalon Wilderness Reserve was established in the centre of the peninsula.

Newfoundland's Avalon was also the inspiration for a cluster of Avalon names in British Columbia in the $20^{\text {th }}$ and $21^{\text {st }}$ centuries. This cluster owed its existence to Jeremiah Crowley: a young man from Western Bay, on the northern promontory of the Avalon Peninsula, who travelled west to British Columbia in 1898 to join in the Gold Rush then underway. Arriving too late to participate, he settled in Vancouver, bringing his family over and establishing the Avalon Dairy in the suburb of Killarney (Hardy, 2014). There is no evidence that Arthurian connotations played any role in the naming of the dairy, and this can be considered to have been eponymic to his place-of-origin. The dairy prospered, and Jeremiah's son Everett went on to serve on the Vancouver Parks Board, having a park named in his honour that included Avalon Pond, named after his family's dairy (Bollwitt, 2009). The local tradition of the Avalon name and its more general association with idyllic locales subsequently prompted the development company Wesgroup to adopt it for a new condominium complex located on the north bank of the Fraser River, south of Avalon Pond, which is slated to include a riverside leisure space named Avalon Park. While the development is located on the riverside, rather than a peninsula, it otherwise resembles those urban peninsular presqu'tlles - such as Rouen's La Presqu'île district - that have sought to regenerate inner city peninsulas and turn them into lucrative real estate complexes complete with green spaces (see Fleury \& Raoulx, 2006, pp. 17-18). The place name 'Avalon' in this context is complex in that it operates on multiple levels: as an evocation of islandness (through referring to an original island locale) that adds associative value to a commercial property; as an invocation of a mythic/romantic place whose association (however tenuous) can add another type of allure to a redevelopment site; and as a local place association that plays off the rural connotations of the original Avalon Dairy. Linking these is a slender but enduring onomastic filament that winds back east across Canada to Newfoundland and then on east again to Somerset, and to Tudor England more generally. In this context, islandness is a quality detached from topographical definition and, instead, principally stands for a specific, bounded, cultural landscape of the type Suwa (2007, p. 6) identifies as a shima, i.e., a territory in which cultural associations are so "deeply intermeshed" that they define the space for its human inhabitants and those who seek to represent it. As he elaborates:

The idea of shima, in this regard, becomes a key for exploring the idea of island as embedded in cultural formations. Islands are, in this regard, 'cultural landscapes' where imagination takes forms of reality. Cultural landscapes are the manifestation of human impact on the environment and manifest themselves visually and through other senses. (Suwa, 2007, p. 6) 
As Suwa (2007, p. 6) also identifies, in this regard, islands can be considered "works of imagination" whose representation - through practices such as place naming - disperses the imagination of islandness (specific and general) across a range of contexts and locations.

As part of a different trajectory of Avalonian place naming, the $17^{\text {th }}$ century designation of the Newfoundland peninsula was also echoed in the late $20^{\text {th }}$ century in another regional context, being applied by geologists to a composite terrane that split from the supercontinent' of Gondwana in the Ordovician period around 460 million years ago. This splinter, comprising parts of (present-day) south-eastern Ireland, England, Wales, the French-Belgian border region, eastern Newfoundland, Nova Scotia, southern New Brunswick, and areas of the New England coast, was named Avalonia after the peninsula that forms part of it (Carney et al., 2000, pp. 9-10). Somewhat fancifully, the presence of eastern Newfoundland in the centre of this micro-continent led geologist Herm Dover (n.d.) to identify Newfoundland's Avalon Peninsula as "the heart of Avalonia," lending further mystic association to the name.

\section{Avalons inspired by Arthurian legendry, 1850-1925}

During the $18^{\text {th }}$ and early $19^{\text {th }}$ centuries, the actuality of rural life around Glastonbury, Somerset, was markedly different from the tranquil abundance of Arthurian legend, with grinding poverty forcing many off the land and into migration, mainly to North America (P. Clark, 1979). One individual who took a different direction was James Austin. Born in 1809 in Baltonsborough, a small village on the flatlands $3 \mathrm{~km}$ south-east of Glastonbury, Austin travelled to Australia in 1835 to enhance his prospects. He prospered in his new home and purchased a tract of farming land south of the Victorian city of Geelong around 1840, which he named the Avalon estate. The naming is notable, in terms of the parameters sketched in this article, in that it appears to have commemorated Austin's place of upbringing by association with its Arthurian connection and through its interpretation as Avalon. Austin's agricultural enterprise flourished and in 1854 he returned to England as a man-of-means, becoming mayor of Glastonbury in 1858 and purchasing Glastonbury Abbey House and the adjacent abbey ruins in 1864 (Pearse \& Nagel, 2015). While Austin focussed his energies on Glastonbury in his final years, the Victorian estate he had relinquished was subsequently recognised as a named locality. In the latter part of the $20^{\text {th }}$ century, it became the site of Avalon airport (which now serves as Melbourne's second airport) and the adjacent Avalon Coastal Reserve. The trajectory that saw Austin depart Somerset, establish himself and the Avalon name in Australia, and then return to purchase the abbey at the centre of 'the Somerset tradition' was a highly personal and idiosyncratic one, and the place naming involved was markedly different from that undertaken by the series of other individuals influenced by Arthurian legendry identified below.

Interest in Arthurian themes in the UK and across the anglophone world was boosted in the $19^{\text {th }}$ century when the Medieval period again attracted the attention of artists and scholars. One of the most notable (re-)popularisers of Arthurian romance was the poet Lord Alfred Tennyson, who wrote twelve Arthurian-themed verse narratives between 1842 and 1859, known collectively as the Idylls of the King. Tennyson was a high-profile literary figure in the United Kingdom and enjoyed royal patronage as poet laureate between 1850 and his death in 1892. His Idylls were amongst his best-known works and were popular with an international anglophone public. King Arthur was a particular beneficiary of Tennyson's 
prose, becoming widely regarded as an exemplary inspirational figure for boys and young men across the British Empire and in the United States (as manifest in the US publication, The Boy's King Arthur [Lanier, 1880], and as discussed by Sharapkova [2015]). Indeed, the legend became popular enough to be satirised by Mark Twain in his 1889 novel A Connecticut Yankee in King Arthur's Court (adapted for the screen in 1948 by director Tay Garnett).

While Avalon plays a minor role in Tennyson's Idylls (spelled as 'Avilion', after Malory), its description in Morte d'Arthur (Tennyson, 1842, lines 257-261) both derives from previously discussed accounts and has several novel inflections:

To the island-valley of Avilion,

Where falls not hail, or rain, or any snow,

Nor ever wind blows loudly; but it lies

Deep-meadow'd, happy, fair with orchard-lawns

And bowery hollows crowned with summer sea

The first novel aspect concerns the specification of Avalon as an island "valley." Avalon (in its various spellings) had previously been described as a (whole) island and usually (albeit implicitly) as a small one. Tennyson's characterisation of it being an "island-valley," i.e., a valley within an island, thereby marks a departure and facilitates comparisons with other island valleys (and valleys more generally). The specification of "orchard-lawns" is also novel. Previous accounts had rendered the island of Avalon as having an abundant but essentially natural environment; Geoffrey of Monmouth (ca. 1150/1995), for instance, declaring that "all cultivation is absent." By contrast, Tennyson describes the presence of "orchard-lawns," i.e., orchard areas in which the grass is regularly cut. This characterisation recalls the highly manicured landscapes promoted by landscape designers such as Capability Brown, in which the decorative function is primary, and represents a modernisation of the image of Avalon that might appeal to a $19^{\text {th }}$ century readership.

The first international Avalon-named location that has been identified as inspired by the $19^{\text {th }}$ century vogue for Arthurian themes was located some sixty kilometres north of Athens, Georgia. The town was founded by businessman Richard Dempsey Yow in 1882 and, while it is unknown whether Tennyson's verse was a specific influence, it was reportedly named after the isle of Arthurian legend (Krakow, 1975, p. 10). Soon after the Georgia community was christened, Ella Whitney, the sister-in-law of Los Angeles-based real estate developer George Shatto, named another, better-known location. In 1887, Shatto purchased Santa Catalina Island, one of the Californian Channel Islands, located $75 \mathrm{~km}$ south-west of Los Angeles, perceiving it to have potential as a tourist destination. At the time of purchase, there was one small settlement on the island, named Timm's Landing, positioned in a wide valley on the island's sheltered eastern coast. Whitney visited with Shatto soon after his purchase of the island and was sufficiently impressed by the valley to compare it to Avalon, which she was familiar with as an aficionado of Idylls of the King. She subsequently proposed the Arthurian name for her brother-in-law's new development (World Port Source, n.d.). The name stuck and acquired fresh connotations as the valley developed as a major centre for maritime tourism in the early $20^{\text {th }}$ century with its facilities being upgraded to include the lavish Casino ballroom in 1929. The Casino and the music played at it provided an important element in the promotion of the town and broader island as an idyllic tourism destination. 
Indeed, the song 'Avalon', written by Al Jolson and B. G. Desylva in 1920, telling of a brief and vivid love affair there, was widely performed and recorded by various artists, playing a significant role in promoting the location. Evidence of Avalon's success in promoting its charms was apparent as early as 1900 . When a new residential development was established on the Mayo River, in North Carolina, to house workers at a mill that had opened in 1900, the mill supervisor, W. C. Ruffin, named it after Catalina Island's Avalon (Dillon, 1974). The community was abandoned after the mill burned down in 1911, but the name 'Avalon' extended to a nearby valley and the local dam. Along with these examples, another notable Avalon was developed on the East Coast of the US in the late $19^{\text {th }}$ century on the southern tip of New Jersey's Cape May. This was named in 1887 in a similar manner to Catalina Island's main settlement; in this case, the naming was the initiative of the Rev. Charles $\mathrm{H}$. Bond, secretary of the Seven Mile Beach Company and a devotee of Arthurian literature (Roncace, 2012). The name featured prominently in initial destination branding and continues to do so in contexts such as the designation of the upmarket Icona Avalon hotel.

While, as previously discussed, Australia's first (known) Avalon was located in Victoria, inspired by James Austin's place of birth and upbringing, the naming of its second such locale was influenced by a type of association closer to the US examples discussed above. In 1921, real estate agent Arthur J. Small secured rights to develop a subdivision in an area of Sydney's Barrenjoey peninsula known as Priest's Flat, built himself a house, and began actively marketing lots. As his daughter, May Hunt (1985), later recalled, her father chose the name of his new house and of the suburb in the following fashion:

Late in 1921 my father awoke my mother in the early hours of the morning to tell her of his inspiration to name the place Avalon Beach. I understand that he had in mind Avalon, the earthly paradise of Celtic mythology, supposedly a valley near Glastonbury, Somerset, England. With its connection with King Arthur and his knights of the Round Table it is immortalised in Tennyson's Idylls of the King... Soon afterwards my father had a signboard erected at the top of Bilgola Hill as the road descends into Avalon which read: "Behold the Vale of Avalon - Tennyson".

This theme was also emphasised by Small with his explanation in marketing materials that "the word 'Avalon' means 'An Earthly Paradise'." The marketing appears to have been a success, with the lots soon being sold and a community taking root in what is now an expensive and exclusive area.

Along with the direct association of the place naming discussed above, there are other, less direct chains of association that may have been inspired by Arthurian legendry. One such association concerns boats. In Arthurian legendry, the wounded king is ferried to the island of Avalon, and this association seems to be apparent in the naming of several vessels in the 1800s and early 1900s. The association of a village and an adjunctive islet on Tilghman Island, in Chesapeake Bay, Maryland, with Avalon appears to be related to vessel naming. The village's origins are entwined with the development of shipping around the island in the 1880s-1920s and, in particular, the construction of a wharf that received steamboats from Baltimore operated by the Maryland Steamboat Company. One of the steamboats working the route in the 1880s was named the Avalon. While the reason for her name is unknown, it was not atypical of steamboats in that period, with a rival boat being named the Minerva, after 
the Greek Goddess of war and wisdom (Choptank River Heritage, n.d.). Along with steamboats, local oyster shucking operations also used the area, and discarded shells built up a base in the shallow water that eventually formed a small islet. In a process that is still unclear, the name 'Avalon' was given to both the islet (which was subsequently enhanced with landfill and has been home to the Tilghman-On-Chesapeake Yacht Club since 1990) and to the nearby village (Eshelman \& Scheffel, 2002, p. 74).

The examples discussed above are part of a larger process of naming that involved the traditions and values of a European culture being imposed on landscapes that were home to Indigenous cultures that had their own traditions of place naming and of individual place names. In this manner, the impositions of the name 'Avalon' on various geographical features and/or communities was a far less 'romantic' exercise for Indigenous populations than it was to settler culture. Fanciful imaginations of Arthurian times in the New World that became inscribed as place names were just as much a form of cultural imperialism as any other erasure of Indigenous traditions. In another level of irony, there were a number of plantations named 'Avalon' in $18^{\text {th }}$ - and $19^{\text {th }}$-century America, such as the Avalon Plantation on Bayou Teche, Louisiana (Goodwin and Associates Inc., 1991, pp. 18, 23, 25) in which transported, enslaved Africans and, later, low-paid workers toiled in conditions that were far from idyllic however charmed the lives of their owners may have been. These institutions have been commemorated in various ways that are strikingly dissonant to the historical reappraisals prompted by the Black Lives Matter movement (Maraj et al., 2019). US media mogul Ted Turner's lavish Avalon Plantation House, built on an eponymous property in north-western Florida in 1938, and Avalon Plantation Drive in Missouri City, for instance, are clearly designations that merit discussion in such contexts. In terms of African American culture, it should also be noted that, once designated, places can develop associations that are not determined by the original meanings of their names. Avalon, Mississippi, a small community founded in the early $1900 \mathrm{~s}$, looked to be in terminal decline in the mid-late $20^{\text {th }}$ century before the residence of celebrated Blues musician Mississippi John Hurt was turned into a tourist site. Today, aficionados can visit the home of a performer whose 1922 composition 'Avalon Blues' celebrated the locality for the friendliness of its African American community, providing the place name with another set of associations.

\section{The profusion of Avalons in the $20^{\text {th }}$ and $21^{\text {st }}$ centuries}

While the cases discussed above are significant for being directly influenced by the mid-late $19^{\text {th }}$ century vogue for Tennyson and Arthurian legendry, the most substantial profusion of Avalon place names has occurred over the last century, as new residential areas have been developed to cope with soaring population numbers; the US population, for instance, tripling between 1900-2000 (US Census Bureau, 2002), and the Australian population increasing seven-fold in the same period (ChartsBin, 2009). In this context, many place names were allocated more speedily and in greater volume than in previous periods. While the general nature of decision-making processes about place names undertaken at corporate and local government levels does not appear to have been studied on any systematic basis (Alderman, 2008) the results of such processes are apparent in the names of modern residential developments, suburbs, and towns. With particular regard to the allocation of anglophone heritage place names to New World locations in recent decades, Donald Mitchell (2000, p. 10) has asserted that these effectively serve "the demands of post-modern consumers to 
purchase symbolic capital in the form of unique products and experiences that reflect a bygone era." The allocation of 'Avalon' as place name in a wide variety of locations exemplifies this tendency, and is marked (to the extent of heavy-handedness) in the Avalon Terrace area, located $25 \mathrm{kms}$ south of Houston, Texas, which was developed in the 1980s and continues its branding by including streets with names such as Misty Lake Lane, Avalon Lake Lane, and Waterlily Lane. Similarly, Avalon Park, on the outskirts of Orlando, Florida, typifies a related type of development. Opening in 2003, and still expanding, the orderly, park-like residential estate is built around various shallow lakes and features a nest of village-type communities and green spaces, evoking vague, romanticised notions of Englishness. In other contexts, the ambition behind place naming has exceeded the reality of the developments that the name has been applied to. Avalon Gardens, Los Angeles, is a prime example of this. Established in 1941 to house military families, Avalon Gardens is primarily notable (within the focus of this study) for the disjuncture between its elysian name and the severe social problems that afflicted it in the 1970s and 1980s. During this period, it served as the base for the violent Avalon Gardens Crips gang before the Housing Authority of Los Angeles intervened and erected walls and fences around the development, limiting movement, increasing surveillance, and reducing crime rates (J. Mitchell, 1996) by effectively turning it into 'Fortress Avalon'.

In recent years, the combination of Avalon's traditional association with fertile soils and orchards and Avalon's popularity within New Age circles (particularly manifest in Glastonbury itself - see Bowman, 2007) has also influenced the naming of counter-cultural developments, such as the Avalon Organic Gardens and EcoVillage. The eco-enterprise was established in northern Arizona in 1994 before relocating to Tumacacori, in the south of the state, in 2007, where it occupies 89 hectares and has 115 residents. Its website states its operation and orientation in the following terms:

We are a fully operational micro-society showcasing the success we have had incorporating a modern lifestyle within the sustainable context of a land-based society. In addition to pursuing the classical "off-grid" definition of sustainability, the EcoVillage also pursues self-sufficiency by providing meaningful vocational work, ongoing education, spiritual exploration, and dynamic cultural experiences to each of the committed, residential members of the EcoVillage. (Avalon Organic Gardens and Ecovillage, n.d.)

Whether the eco-village lives up to its lofty aspirations or not, it clearly has a coherent mission and vision that utilises 'Avalon' as a brand name to suggest an integrated ecological and spiritual lifestyle experience. It is also host to other institutions, such as the grandly named University of Ascension Science and The Physics of Rebellion. The village's and university's New Age resonance with Arthurian myths is manifest in many of their promotional images (e.g., Avalon Organic Gardens and EcoVillage, 2018).

In addition to the populated areas that have been the principal focus of this article, the name 'Avalon' has also been given to a number of public parks in the US, Canada, and New Zealand, presumably to emphasise the calmness of their amenity. One notable example of this is Avalon Park and Preserve on Long Island, New York, on the south-east edge of Stony Brook Harbor. The area was established in 1998 and was designed to produce what Hill and Geffel (2011) have described as a "sequential journey through a series of 'natural gardens' that 
reflect the changing character of the native northern Long Island landscape" together with a labyrinth. Hill and Geffel (2011) have asserted that "almost instantly" after the park and preserve opened it was "embraced as a sacred space, hosting candlelight vigils following the attacks of September 11, and providing garden therapy to its many visitors over the following years."

With regard to residential developments named Avalon over the last four decades, new inflections and connotations concerning the referent locale may also have come into play in place naming. Along with the literary underpinnings of several of the cases discussed above, new media forms such as contemporary popular music, literature and cinema have repopularised the term Avalon in different manners. Roxy Music's 1982 album Avalon returned to the Arthurian theme and represented Avalon as what singer-composer Brian Ferry described as "an enchanted island [...] the ultimate romantic fantasy place" (R. Clark, 2004, para. 7). In the following year, Marion Zimmer Bradley's novel The Mists of Avalon was published, focussing on the female characters of Arthurian legend and opening it up for a new audience. The volume was commercially successful and spawned six sequels and an eponymous television mini-series, which aired in 2001. By contrast, Barry Levinson's nostalgic 1990 film Avalon was set in the 1940s and centred on an imaginary suburb of Baltimore similar to the one that the film maker grew up in. Levinson has described its title as reflecting a place in Celtic mythology said to be "the home of the heart" (Liewer, 1990, para. 14). This characterisation provides a diffuse, New-Ageish and effectively disemplaced sense of the mythical-historical Avalon as a referent. But, while Levinson's suburb may have been imaginary, and his notion of Avalon vague, the association of the mythic place and the city has recently been cemented through the construction of the Avalon 555 President residential complex on Baltimore's eastern harbour, whose marketing pitch promises that you can "live your life effortlessly" (Avalon Communities, 2019) in its luxury surrounds.

Somewhat surprisingly, despite the proliferation of Avalons in the $20^{\text {th }}$ and $21^{\text {st }}$ centuries, there is only one (natural) island that carries the name. This is a small island (around 3400 square metres in size) at the southern end of White Lake in Ontario, Canada, which is now connected to a narrow peninsula of land to its west by a short walkway. Fittingly for a place named after a mystical isle, no official registers or local sources contacted during research for this article had information about the island's name or when it may have first been adopted. The island is now home to a single residence with its own boathouse. It thereby aptly symbolises the process by which the grand visions behind enterprises such as the founding of an English colony in the New World in the 1620s have been scaled down in successive years, with the Avalon name being increasingly applied to commercial developments and to private residences whose idylls revolve around everyday comfort and privacy.

\section{Conclusion}

The discussions advanced in this article have identified that the name 'Avalon' functioned as a vogueish "precedent toponym" (Kalambet, 2015) in its earliest colonial application, to a peninsula in Newfoundland, evoking the then-topical 'Somerset tradition' of English Christian folklore. It was subsequently applied with Tennysonian resonance to areas in places such as Catalina Island and Cape May, in the US, and on Sydney's Barrenjoey Peninsula. Other, more recent uses have either relied on personal "commemorative" (Brink, 2015, p. 159) place associations in Victoria and Vancouver, or else more diffuse senses of "magnetism," 
"charm," and/or "mystique" (Kalambet, 2015, p. 17). In the case of areas with no connections to waterways, Arthurian legendry, and/or the 'Somerset tradition', we can observe the once highly evocative term 'Avalon' to have become an essentially weak and even relatively arbitrary one within social lexicons. We might well postulate, in this regard, that multiple uses of the term have increasingly depleted (rather than enhanced) its semiotic patina. The romantic island increasingly appears lost in the mists of time, growing faint and fuzzy while its name lives on and multiplies. In this process of associative diminution, the islandness of the referent place has also paled into insignificance in odd symmetry with the plains around Glastonbury itself, which are now far drier than they were in the Medieval period. Fittingly, in this regard, one of the most recent uses of 'Avalon' as a precedent toponym has been in those plains, which have become (optimistically) referred to as the Avalon Marshes by groups such as the Avalon Marshes Landscape Partnership (n.d.) scheme, whose website characterises that the marshes are "a magical wetland landscape" lying at the "heart" of Somerset's levels that merit restoration. In this manner, we can perceive the association of Glastonbury and Avalon forged by Geoffrey of Monmouth in the $12^{\text {th }}$ century to have dispersed internationally in anglophone locales and then to have been reinscribed in its original location in a process of historical reimagining and related place naming that renews its identity in the modern era. In all this, islandness floats as a highly mutable entity, detached from topographical definition, and more closely resembles the qualities of shima - bounded cultural landscapes whose deeply intermeshed associations can be deployed in a variety of contexts. The imaginative acts of place naming detailed in this article can be seen as engagements with reified aspects of islandness, as much as with any actual island (whether it existed or not). The multiple Avalons discussed in this article are thereby works of imagination, however pale that imagination may have grown.

\section{Acknowledgements}

Thanks to Gordon Handcock, Philip Hiscock, and Geoff Searle for their assistance with research for this article and to Marea Mitchell for her comments on an earlier draft.

\section{References}

Alderman, D. H. (2008). Place, naming and the cultural interpretation of landscapes. In B. Graham \& P. Howard (Eds.), The Routledge research companion to heritage and identity (pp. 195-215). Routledge. https://doi.org/10.4324/9781315613031-11

Ashe, G. (1957). King Arthur's Avalon: The story of Glastonbury. Collins.

Avalon Communities. (2019). Avalon 555 President. Baltimore Apartments. https://www.avaloncommunities.com/maryland/baltimore-apartments/avalon-555-president/

Avalon Marshes Landscape Partnership. (n.d.). The Avalon Marshes. http://avalonmarshes.org/the-avalon-marshes/

Avalon Organic Gardens and EcoVillage. (n.d.). Avalon Organic Gardens \& Ecovillage. Numundo. https://numundo.org/center/united-states/avalon-organic-gardens-ecovillage/

Avalon Organic Gardens and EcoVillage. (2018, June 20). Welcome to the campus of The University of Ascension Science \& The Physics of Rebellion [Attached image] [Status update]. Facebook. https://www.facebook.com/avalonorganicgardens/photos/a.333636120015695/1805 $\underline{603019485657 /}$ 
Barney, S. A., Lewis, W. J., Beach, J. A., \& Berghof, O. (Eds.). (2006). The etymologies of Isidore of Seville. Cambridge University Press. https://doi.org/10.1017/cbo9780511482113

Bollwitt, R. (2009, January 6). Vancouver history: Avalon Dairy [Blog post]. Miss 604. https://miss604.com/2009/01/vancouver-history-avalon-dairy.html

Brink, S. (2016). Transferred names and analogy in name-formation. In C. Hough (Ed.), The Oxford handbook of names and naming (pp. 158-166). Oxford University Press. https://doi.org/10.1093/oxfordhb/9780199656431.013.43

Carney, J. N., Horak, J. M., Pharaoh, T. C., Gibbons, W., Wilson, D., \& Barclay, W. J. (2000). Precambrian rocks of England and Wales. Chapman and Hall.

ChartsBin. (2009). Historical population of Australia, 1788 to future. http://chartsbin.com/view/eoo

Choptank River Heritage. (n.d.). Fate of the Choptank River steamboats Joppa and Avalon [Blog post]. https://choptankriverheritage.org/wp3/memories-of-joppa-and-avalon/

Clark, P. (1979). Migration in England during the late seventeenth and early eighteenth centuries. Past \& Present, 83, 57-90. https://doi.org/10.1093/past/83.1.57

Clark, R. (2004, June 1). Roxy Music's “Avalon”. MIX. https://www.mixonline.com/recording/roxy-musics-avalon-365419

Coates, R. (2013). Onomastics. In C. A. Chapelle (Ed.), The Encyclopedia of applied linguistics (pp. 4320-4315). Blackwell Publishing.

Colony of Avalon Foundation. (n.d.). Colony of Avalon. http://colonyofavalon.ca/

Colony of Avalon Foundation. (2016). The Beothuk at Ferryland. https://www.heritage.nf.ca/articles/exploration/beothuk-at-ferryland.php (Original work published 1999)

Cusack, C. (2018). The Glastonbury Thorn in vernacular Christianity and popular tradition. Journal for the Study of Religion Nature and Culture, 12(3), 307-326. https://doi.org/10.1558/jsrnc.33523

Dillon, V. (1974). Avalon: A brief history of a fateful town.

Dover, H. (n.d.). Heart of Avalonia. Retrieved October 20, 2020, from https://www.heartofavalonia.org/heart.html

Eshelman, R. E., \& Scheffel, C. W., Jr. (2002). Maryland's Lower Choptank River cultural resource inventory. Choptank River Heritage. http://choptankriverheritage.org/Documents/Lower\%20Choptank\%20Inventory.pdf

Fleury, C., \& Raoulx, B. (2006). Toponymy and taxonomy. Shima, 10(1), 8-20. http://doi.org/10.21463/shima.10.1.04

Fuller, T. (1881). The history of the worthies of England (vol. 2). Cambridge University Press.

Geoffrey of Monmouth. (1995). The life of Merlin (J. J. Parry, Trans.). University of Illinois. Retrieved from https://www.sacred-texts.com/neu/eng/vm/vmeng.htm (Original work published ca. 1150)

Gerald of Wales. (2001). The tomb of King Arthur (J. Sutton, Trans.). In A. Lupack \& B. Tepa Lupack (Eds.), The camelot project. https://d.lib.rochester.edu/camelot/text/gerald-of-wales-arthurs-tomb (Original work published 1193) 
Goodwin and Associates Inc. (1991). Supplemental archeological investigations of Lower Bayou Tech, St. Mary Parish, Louisiana. Report for US Army Corps of Engineers New Orleans District.

Government of Canada. (2020). Canadian Geographical Names Database. Geographical names in Canada. https://www.nrcan.gc.ca/maps-tools-andpublications/maps/geographical-names-canada/10786

Hardy, J. (2014). Avalon Dairy: Dear dairy. MONTECRISTO Magazine. https://montecristomagazine.com/magazine/autumn-2014/avalon-dairy

Hayward, P. (forthcoming, 2021). Avalon place name data set. https://www.islandresearchph.com/research-notes.html

Hill, K., \& Geffel, M. (2011). Avalon Park and Preserve [Landscape Performance Series Case Study Brief]. Landscape Architecture Foundation. https://www.landscapeperformance.org/case-study-briefs/avalon-park-and-preserve

Hunt, M. (1985). The naming of Avalon Beach. Typed document archived at Avalon Beach Historical Society, New South Wales, Australia.

Intergovernmental Committee on Surveying and Mapping. (n.d.). Place names - Foundation spatial data. FSDF LINK Platform. https://placenames.fsdf.org.au

Kalambet, Y. (2015). Verbalization of the precedent toponym Avalon in Arthurian discourse of XV-XXI centuries. Science and Education a New Dimension: Philology III, 11(56), 16-18.

Krakow, K. (1975). Georgia place-names and their origins. Winship Press.

Lanier, S. (1880). The boy's King Arthur. Charles Scribner's Sons.

Liewer, S. (1990, November 1). Avalon: The movie, the reality. South Florida Sun-Sentinel. https://www.sun-sentinel.com/news/fl-xpm-1990-11-01-9002220734-story.html

Maraj, L. M., Prasad, P., \& Roundtree, S. V. (2019). \#BlackLivesMatter: Pasts, presents, and futures. Prose Studies, 40(1-2), 1-14. https://doi.org/10.1080/01440357.2019.1668638

Mitchell, D. (2000). Cultural geography: A critical introduction. Blackwell.

Mitchell, J. L. (1996, June 5). Trouble at the gate. Los Angeles Times. https://www.latimes.com/archives/la-xpm-1996-06-05-me-11821-story.html

Nash, J. (2016). Do island toponymies exist? Island Studies Journal, 11(2), 339-342.

Nash, J. (2015). 'The how of toponymy': A comment on Tent's 'Approaches to Research in Toponymy'. Names, 63(4), 233-236. https://doi.org/10.1080/00277738.2015.1118983

Nash, J. (2013). Insular toponymies: Place naming on Norfolk Island, South Pacific and Dudley Peninsula, Kangaroo Island. John Benjamin. https://doi.org/10.1075/clu.9

Nash, J. (2012). Pristine toponymy and embedded placenames on islands. Names, 60(3), 166172. https://doi.org/10.1179/0027773812z.00000000023

Nash, J. (2009). Naming the sea: Offshore fishing grounds as place names on Pitcairn Island and Norfolk Island. Shima, 3(2), 118-131.

Pearse, A., \& Nagel, J. (2015). Convicted Baltonsborough boy makes good in Australia Result: his family in Somerset ends up owning the Abbey. Glastonbury Conservation Society Newsletter, 143. https://glastonburyconservation.org.uk/143/oz.php

Rippon, S. (2008). Making the most of a bad situation? Glastonbury Abbey, Meare, and the medieval exploitation of wetland resources in the Somerset levels. Medieval Archaeology, 48, 91-130. https://doi.org/10.1179/007660904225022816

Roncace, K. (2012, June 4). What's in a name? Avalon Borough. NJ.com. https://www.nj.com/indulge/2012/06/whats in a name avalon borough.html 
Ross, A. S. C. (1958). Notes on some 'pristine' place-names of Pitcairn Island. In M. Cortés, A. G. Blanco, \& A. Tovar (Eds.), Fifth international congress of toponymy and anthroponymy: Proceedings and transactions (pp. 333-337). Acta Salmanticensia.

Sharapkova, A. (2015). American values through the images of the Arthurian myth in educational paradigm of the USA and scouts [sic] literature at the beginning of the XX century. Vestnik Permskogo Universiteta: Rossijskaa i Zarubeznaa Filolgia, 1, 108-118.

Stoltz, T., Warnke, I. H., \& de Bloom, J. (2020). Colonial place names. Oxford Bibliographies Online. $\quad$ https://www.oxfordbibliographies.com/view/document/obo9780199772810/obo-9780199772810-0263.xml

Suwa, J. (2007). The space of shima. Shima, 1(1), 1-9.

Tennyson, A., Lord. (1842). Morte d'Arthur. Retrieved from https://www.poetryfoundation.org/poems/45370/morte-darthur

Tent, J. (2015). Approaches to research in toponymy. Names, 63(2), 65-74.

Toitū Te Whenua: Land Information New Zealand. (2018). New Zealand Gazetteer of place names. $\quad$ https://www.linz.govt.nz/regulatory/place-names/find-place-name/newzealand-gazetteer-place-names

Twain, M. (1889). A Connecticut Yankee in King Arthur's court. Charles L. Webster and Company.

US Board on Geographic Names. (n.d.). The United States and its territories: United States Geological Survey. https://geonames.usgs.gov/

US Census Bureau. (2002). Demographic trends in the 20th Century. https://www.census.gov/prod/2002pubs/censr-4.pdf

Wood, A. A. (2000). Early cartography of Newfoundland and Labrador. Heritage Newfoundland and Labrador. https://www.heritage.nf.ca/articles/exploration/cartographynewfoundland-labrador.php

World Port Source. (n.d.). Avalon Harbor. https://www.worldportsource.com/ports/review/USA CA Avalon Harbor 1511.php

Zimmer Bradley, M. (1983). The mists of Avalon. Alfred A. Kopf. 